\title{
Homeless people: health aspects and experiences with health services
}

\author{
Pessoas em situação de rua: aspectos sobre a saúde e experiências com serviços sanitários \\ Personas sin hogar: aspectos de salud y experiencias con los servicios de salud
}

Michely Aline Rodrigues do Prado' ORCID: 0000-0003-2200-9789

Marcela Gonçalves" ORCID: 0000-0003-0886-1967

Simone Santana da Silva"'! ORCID: 0000-0002-0768-3217

Poliana Silva de Oliveira'v ORCID: 0000-0003-3197-6017

Karen da Silva Santos $v$ ORCID: 0000-0001-5829-5882

Cinira Magali Fortuna ORCID: 0000-0003-2808-6806

'Santa Casa de Misericórdia de Olímpia. Olímpia, São Paulo, Brazil. "Prefeitura Municipal de Guarulhos. Guarulhos, São Paulo, Brazil. "'Universidade do Estado da Bahia. Senhor do Bonfim, Bahia, Brazil. "Nrefeitura Municipal de Orlândia. Orlândia, São Paulo, Brazil. 'Universidade de São Paulo. Ribeirão Preto, São Paulo, Brazil.

How to cite this article:

Prado MAR, Gonçalves M, Silva SS, Oliveira PS, Santos KS, Fortuna CM. Homeless people: health aspects and experiences with health services. Rev Bras Enferm. 2021;74(1):e20190200. doi: http://dx.doi.org/10.1590/0034-7167-2019-0200

\section{Corresponding author:} Cinira Magali Fortuna E-mail: fortuna@eerp.usp.br

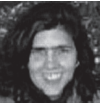

EDITOR IN CHIEF: Antonio José de Almeida Filho ASSOCIATE EDITOR: Priscilla Valladares Broca

Submission: 07-22-2019

Approval: 08-13-2020

\section{ABSTRACT}

Objectives: to analyze the understanding of homeless people living in a city in the countryside of São Paulo about what health is and about their experiences in health services. Methods: a qualitative exploratory study developed through interviews with homeless people and a field diary. The data were organized by themes and the findings were compared to a collective health framework. Results: the explored themes were: "Being healthy for the homeless population", "The search for health services" and "Being a user of health services from the perspective of homeless people". We present the interviewees' understanding of health and their experiences in healthcare services. Along this path, we outline aspects that show the network's weaknesses, permeated by prejudices and discrimination. Final Considerations: this population has conceptions about health and needs that need to be singularly taken into consideration to facilitate access and care.

Descriptors: Homeless Persons; Health Services; Health; Delivery of Health Care; Nursing.

\section{RESUMO}

Objetivos: analisar o entendimento das pessoas em situação de rua, que vivem em município do interior paulista, sobre o que é saúde e sobre suas experiências em serviços sanitários. Métodos: estudo qualitativo exploratório desenvolvido com entrevistas com pessoas em situação de rua e diário de campo. Os dados foram organizados por temas e os achados foram confrontados com referencial da saúde coletiva. Resultados: os temas explorados foram: "O ter saúde para a população em situação de rua", "A busca por serviços de saúde" e "Ser atendido em serviços de saúde sob a ótica de pessoas em situação de rua". Neles apresentamos a compreensão da saúde dos entrevistados e experiências vivenciadas em serviços. Nesse caminho, delineamos aspectos que demarcam fragilidades da rede, perpassadas por preconceitos e discriminação. Considerações Finais: essa população tem concepções sobre a saúde e necessidades que precisam ser consideradas singularmente para facilitar acesso e cuidado.

Descritores: Pessoas em Situação de Rua; Serviços de Saúde; Saúde; Assistência à saúde; Enfermagem.

\section{RESUMEN}

Objetivos: analizar la comprensión de las personas sin hogar residentes en una ciudad del interior de São Paulo, sobre lo que es la salud y sus experiencias en los servicios de salud. Métodos: estudio exploratorio cualitativo desarrollado con entrevistas a personas sin hogar y diario de campo. Los datos se organizaron por temas, y los hallazgos se compararon con un marco de salud colectiva. Resultados: los temas explorados fueron: "Tener salud para la población sin hogar", "La búsqueda de servicios de salud" $y$ "Ser atendido en los servicios de salud desde la perspectiva de las personas sin hogar". Presentamos la comprensión de la salud de los entrevistados y las experiencias vividas en los servicios. Trazamos aspectos que demarcan las debilidades de la red, permeados por prejuicios y discriminaciones. Consideraciones Finales: esta población tiene concepciones sobre la salud y necesidades que deben ser consideradas de manera singular para facilitar el acceso y la atención. Descriptores: Personas sin Hogar; Servicios de Salud; Salud; Prestación de Atención de Salud; Enfermaría. 


\section{INTRODUCTION}

Health workers, especially nurses from public health services, face the challenge of producing unique care for people in vulnerable situations, as is the case of homeless people. This is a portion of the population that is invisible in their differences and specific needs. The inaccuracy of data related to the number of Homeless Population (HP) in Brazil reaffirms the invisibility of this social group and undermines the formulation and applicability of public policies ${ }^{(1)}$. Such reality reinforces an emergency in giving visibility to the existence of these lives in the perspective of guaranteeing dignity, access, respect, and protection.

It is relevant to consider that poverty, among the several possible causes, is one of the elements that makes it impossible for individuals to have basic needs met, such as food, clothing and housing. This context affects their physical, psychological and social development ${ }^{(2)}$. As a consequence, this can influence the maintenance of the existence of a HP. In Brazil, for example, it has been only a decade since the creation of Presidential Decree 7,053 of December 23, 2009, which institutes the Brazilian National Policy for the Homeless Population (PNPSR - Política Nacional para a População em Situação de Rua), and its Intersectoral Committee for Follow-up and Monitoring ${ }^{(3)}$. Implementing public policies, while not guaranteeing social improvements, legitimizes the recognition of HP's vulnerable character and gives visibility to their needs. In 2016, the Institute of Economic and Applied Research (IPEA - Instituto de Pesquisa Econômica e Aplicada) published an estimate stating that HP in Brazil is at around 100 thousand people, $70.0 \%$ of whom live in cities with more than 100 thousand inhabitants and about $6 \%$ live in municipalities with up to 10 thousand inhabitants ${ }^{(4)}$. This points out not only some specificities in treating that population associated with wealth concentration, the capitalist mode of production, but also lack of preparation or even invisibility on part of actions aimed at social policies.

It is relevant to consider that there are several factors that lead people to live on the streets. Among them, it is almost never a personal option, but rather a lack of better alternatives. The most common causes are rapid urbanization, migration to large cities, economic crisis, social inequality, poverty, weakened family relationships, unemployment, alcohol and drug dependence and absence of public policies ${ }^{(5-7)}$. Literature review points to a lack of studies on health needs and specific care for this population ${ }^{(2)}$.

For $\mathrm{HP}$, this scenario of absence of public policies is far from being modified, especially given the various measures adopted, such as Constitutional Amendment 95 (EC 95), approved by the Federal Government, which places a limit on state expenses for the next 20 years. Indeed, this amendment will lead to the scrapping of social policies, especially in the fields of health and education ${ }^{(8)}$. In a scenario in which health has been treated as a commodity, individuals will have access to quality of care equivalent to what they will be able to pay, with evasion of the popular classes ${ }^{(9)}$, which exposes HP, in this case, to a great risk of being unassisted or assisted exclusively by charitable actions.

In Brazil, health is still everyone's right and a duty of the State, as established in the 1988 Constitution ${ }^{(10)}$. Moreover, according to Article 7, the PNHP(3) aims at "ensuring broad and safe access to health, education, housing, services and programs, among others; ensuring the training of professionals and managers to act in the development of public policies; and implementing specialized HP service reference centers".

Implementation of these services started to be supported by the Brazilian Ministry of Social Development (MSD) in 2010. Within the medium complexity services, there is the Specialized Service for Homeless People, which is offered at the Specialized Reference Center for Assisting the Homeless Population (POP Center - Centro de Referência Especializado para População em Situação de Rua). This service specifically assists HP. Furthermore, it has a space for group and social interaction and development of relationships based on solidarity, affection and respect, in order to provide experiences that achieve autonomy, organization, mobilization, and social participation. This service also assists in developing life projects and social and/or family reintegration ${ }^{(11-12)}$.

Considering the above, we confirm that $\mathrm{PH}$ s deserve attention, as does the life trajectory which led them to be in this situation, their conflicts, their daily struggles, the prejudices they face and, above all, it is important to understand their view on health. Thus, it is possible to understand the relevant role of the care network, the professionals and the teams that are involved in this care process. Consequently, the importance of considering the characteristics of such population and of responding to their needs is understood from intersectoral actions coordinated by Primary Health Care, passing through the network points as the demands arise. Undoubtedly, it cannot be disregarded that the role of nursing (and other professional modalities) in this process is real ${ }^{(13)}$.

The scientific literature points out the difficulty of the effective approach and insertion of health services in HP care, as verified in an integrative review ${ }^{(2,6)}$. Situations of prejudice and discrimination, little sensitivity and preparation of professionals when dealing with people who have such complex life situations and who demand a unique way of caring, as well as the need for better articulation between the different State sectors and society are among the difficulties that stand out ${ }^{(6)}$.

Getting closer to HP, articulating their experiences with the political, social, organizational and economic aspects of Brazilian health as well as their experiences with health services can help health professionals to rethink their professional practices and highlight gaps in scientific production for induction of public policies focused on this population. Considering the above, the present study calls into question: what do homeless people think about health and about the care provided in health services?

\section{OBJECTIVES}

To analyze the understanding of homeless people living in a city in the countryside of São Paulo about what health is and about their experiences in health services.

\section{METHODS}

\section{Ethical aspects}

The research was approved by a Research Ethics Committee, as provided for in Resolution 466/2012 of the Brazilian National 
Health Council (Conselho Nacional de Saúde). Moreover, it was authorized by the Municipal Office of Assistance and Social Development (Secretaria Municipal de Assistência e Desenvolvimento Social) of São Paulo. It should also be noted that all participants signed the Informed Consent Form (ICF) and had voluntary participation in the study.

\section{Theoretical-methodological framework}

The present study is based on public health theoretical methodological framework, which holds health as a fundamental right in order to exercise citizenship, and reaffirms it as a right of all people and a duty of the State ${ }^{(14)}$.

\section{Type of study}

This is a qualitative study, which is interested in socially constructed meanings. The Consolidated Criteria for Reporting Qualitative Research (COREQ) was used to guide the methodology.

\section{Methodological procedures}

The interviews were conducted at the POP Center, in a private place and with an average duration of 40 minutes, by one of the researchers, an undergraduate student in nursing, who had previous experience with this type of study. Considering the transitional nature of the participation of the HP group that uses the assistance device in which the interviews were conducted, it was pertinent that they occur when they are contacted; therefore, it was not possible to return the analyzed material. All conversations were recorded on a digital recorder and transcribed in full, which allowed for a fluctuating and exhaustive reading of the material, seeking to capture the relevant aspects to answer the research objectives. For analysis, grouping by themes was carried out.

\section{Study setting}

The study was carried out in a specialized service for HP care, POP Center, in a city in the countryside of the state of São Paulo, Brazil.

\section{Data source}

Data were produced by participation of homeless people of both sexes and who attended the POP Center during the research period. Another data source was a field diary. The number of participants was defined by intentional sampling and saturation based on inclusion criteria: people over 18 and being at the POP Center. The exclusion criteria were: to report being under the effects of alcohol and/or other drugs. If the person was under the influence of any of these substances, the interview was not conducted, but at no time did this happen. In total, 10 people participated in the study.

\section{Collection and organization of data}

The technique for producing the data was carried out through record units (interview and field diary). All interviews took place from October to December 2017 and we used a semi-structured script to trigger dialogue. The field diary, used before and after the interviews, ensured that all observed details, impressions, conversations and experienced feelings could provide further reflections and complement the analysis ${ }^{(15)}$.

\section{Data analysis}

As an organizational strategy for analysis of empirical material, thematic content analysis was used ${ }^{(16)}$. The produced material was organized into thematic units and grouped into themes, starting from a framework in which the statements were arranged from each interview, seeking to preserve their context, bringing together ideas and highlighting differences and singularities. "I" was used for interviewee, followed by numbers from one to ten, according to each research participant.

Finally, the material was interpreted by comparing it to the scientific literature and in light of public health framework. Statements were crossed and consolidated due to the need to organize the data to present the article, constructing the text through what was said by participants and what is evidenced in the scientific literature. The statements were clipped and grouped into themes: "Being healthy for the homeless population", "The search for health services" and "Being a user of health services from the perspective of homeless people".

\section{RESULTS}

Group characterization revealed that age varied from 23 to 67 years old, being 3 women from 23 to 29 years old and 7 men from 28 to 67 years old. Of that group, 5 people were single, 2 were divorced and 3 were in a stable relationship. Concerning education, 3 didn't complete elementary school and 2 completed elementary school, 2 didn't complete high school, 2 completed high school, and 1 reported incomplete university studies.

Time on the streets by the interviewed people varied between 3 months and 20 years. According to them, the main reasons that led them to live on the streets were unemployment, use of alcohol and other drugs, and the breaking of family ties, elements that corroborate the findings of another study ${ }^{(17)}$.

Demystifying the thought that HP is composed only of 'beggars' and unemployed people ${ }^{(5)}$, our research confirms that 7 of the participants perform some work activity as a source of income. Even though they are mostly informal jobs ("gigs"), services are aimed at civil construction, unloader, pamphlet delivery, among other functions. Furthermore, 2 people reported being beneficiaries of Bolsa Família Program (Bolsa Família or "Family Allowance" is a social welfare program of the Brazilian government, part of the Fome Zero network of federal assistance programs); therefore, it was used as a source of income and 1 interviewee reported being retired.

Concerning the search for health services, 2 participants reported continuous monitoring and the others reported seeking clinical care only in emergencies. As for their experiences in health services, the study participants revealed positive and negative experiences.

Next, we will present the thematic nuclei that were built in the thematic analysis of data, namely: "Being healthy for the homeless population", "The search for health services" and "Being a user of health services from the perspective of homeless people". 
Homeless people: health aspects and experiences with health services Prado MAR, Gonçalves M, Silva SS, Oliveira PS, Santos KS, Fortuna CM.

\section{Being healthy for the homeless population}

Participants brought their perspective on health, being understood as absence of disease, as well as quality of life considering aspects that permeate daily life and habits of life. In the statement below, it is possible to verify the understanding of health as the absence of disease, pain and aggravation:

It is you being well, not feeling any pain. For me, health is that you are well. (14)

I think health is everything, right? [...]. Loneliness is complicated and all, but at least if the person is healthy [...]. As they say, "he has no money, he has nothing, but he is healthy, you know, it's okay" [...]. I think we help health a lot by not doing extravagance. (I7)

Health associated with risk of contamination by the Human Immunodeficiency Virus (HIV) is observed, according to the following statement:

Ah, that's all. You have to take care, because the risk of contamination [by HIV] is very high. (I2)

In contrast to the previous testimonies, the following one presents the perspective of health as something that goes beyond physical/biological dimensions:

Health is not just what's inside us, it's also quality of life, [...]. A good diet, always being clean... Maintaining personal hygiene is also part of good health [...]. (I1)

For me, to be healthy, I need God first, then I need a job [...] like this, we can take better care of our health. (15)

It is to live well, mentally and bodily. To eat well. It's... Psychologically well. And well with the family, [...] the health of the human being is the family [...]. (18)

Participants also identified health as relevant to human life, being "everything" or the path to "everything".

Health is everything, without it, if the person is not healthy, he has nothing [...]. We can get the rest later. (I2)

With it [health] you get the rest... Get everything you can handle. (110)

\section{The search for health services}

Most participants reported that they were not followed up in health services and that the search occurs only in cases of extreme need, seeking services to meet their demands, relief and pain management:

Yeah, isn't it? Only when I'm in pain, or something. (I2)

[...] I only go when I'm bad [...] when I can't take it anymore. (I3)

I only went to the doctor when I had fractures, when I had more serious illnesses, like pneumonia [...]. (I5)
I manage not to go as much as possible. But in the last case, I have to go, there's no way. (16)

Not because that is like hunger, you look for it when you are [in need of it]. (17)

I was admitted when I got tuberculosis. (19)

Other participants stated that they were followed up more frequently:

[...] I am treated at UETDI [...]. (I1)

Every month [follow-up frequency]. (19)

\section{Being a user of health services from the perspective of homeless people}

Homeless people are stigmatized and adopt an attitude and behavior based on the context they are inserted.

One of the participants reported that in order to be admitted at a health service, a serious and sometimes even aggressive attitude must be adopted:

[...] You live on the street, so you [...] you have to be clear and direct [...] kind of aggressive. [...] The person looks at your face and sees that you [...] need that. So, they tend to you quickly so you can get out of their way, but it's not good. But they treat us. (16)

Others identified that there must be an exchange in the way of relating to professionals, so that service happens effectively:

[...] It's an exchange ... I give you respect to be respected, regardless of the health problem you have. (I1)

[...] Because there are many homeless people who are very ignorant, they do not deserve a good service. (I2)

The statement below shows the understanding of the subject in which the illness ended up becoming a vicious circle and the improvement will only come with changes in the reality of their social context.

[...] What are you going to do with us homeless people? There's nowhere to hide, you have to go back to the street again. Then it rains, you get caught in the rain and cold [...]. They are not to blame, it is true, they are not to blame. But are we to blame for being abandoned on the street? I just left the health center [...] it starts to rain, there is no place to hide [...]. Then what I took there of saline, medicine, what will it do? Will it have any effect? It won't. (I3)

Concerning the treatment received during the visit to the service, statements point to some type of discrimination by the health team:

We live this directly, discrimination, right? [...] (15)

In most of these health centers there, not all workers, but some of them do this type of situation [...] with a homeless person. (I8) 
Others believe that the service distinguishes between service from HP and people with a fixed address, interfering with the behavior of professionals who provide care:

[...] Like us homeless people, noticing the way people treat us, disgusted, with ill will. We end up realizing this, because when you are a member of society, service is different. But when you are no longer part of society, service is different. (I3)

[...] They treat very badly homeless people. Now if you get there well dressed, it's something else. Now if I get there like this, I'm seen as a thug. (16)

On the other hand, in some statements positive experiences are brought:

I am treated well in any hospital, any health center I go to. (I1)

Ah, it was good. I've always been well treated, thanks to God. I never suffered prejudice. (I2)

I was well treated well received. (18)

An interviewee recognizes the type of care he should receive and that there are public policies that guarantee this right:

[...] It doesn't matter if you're a beggar or not. Service has to be equal to equal. [...] Imagine you have an idea, and when it is time to put it into action, it just doesn't get off the drawing board. [...] It never gets off the drawing board. (I3)

At the end of the interview, a conversation with 16 was recorded in a field diary, who asked the researcher about her real interest in conducting the research with the homeless population. This moment suggests innumerable reflections, whether within the institutional responses offered by the establishment to populations that are historically neglected and blamed for their own condition or for the daily life which they lead, associated with the stigmatization that builds different realities in the lives of these people, or even in what it involves the exercise of autonomy by this population, which violates socially normalized forms of life. She mentions to the interviewer that "recording" and "paper" were nothing and what was relevant is "eye to eye", that the truth is only known by those who know the experience. She argued about the practice of health professionals, emphasizing that it was not enough for a single person to care (researcher), but that others, who make up the same academic environment, should approach this reality. She said that, sometimes, "new graduates" are influenced by the work environment and lose the vision of "quality health for all", becoming another one who treats them unfairly, indifferently and lacking respect, as some professionals do.

\section{DISCUSSION}

With some participants in the present study, an understanding of health was observed as something that goes beyond the absence of disease. Being healthy is mentioned as not being sick or not feeling pain, but it is also referred to in an interconnected way as achieving quality of life, having a job, a family, bringing together aspects that encompass the health needs ${ }^{(18)}$ of human beings; these needs are neglected in the context of HP's life.

The World Health Organization ${ }^{(19)}$ defined health as "a state of complete physical, mental and social well-being and not merely the absence of illness or infirmity". Despite being an advanced definition for the time, criticisms are perceived in relation to this concept, as it is unattainable for a large part of the population, even more so when faced with state neglect and social vulnerabilities, such as HP. The Brazilian Organic Law advances this definition and warns us of the fact that health levels will express the country's social and economic organization. Thus, health is marked by determinants and conditions such as food, housing, basic sanitation, income, leisure and access to goods and services (Law 8.080/90) ${ }^{(20)}$. In this regard, it is valid to think that between individual and society there will always be a zone of tension; thus, there is no way to think about complete social well-being, the achievement of full satisfaction is impossible. Therefore, health can be considered a state of reasonable harmony between subjects and their own reality ${ }^{(21)}$.

Homeless people face a vulnerable, different and hostile environment, which can recompose them as new people within a new social environment, due to the presence of situations of violence, hunger and fear, resulting from situations such as homelessness, lack of money, lack of stable employment, lack of essential documents to exercise citizenship, lack of access to education, and even finding it difficult to receive health care ${ }^{(22)}$. It is also necessary to face loneliness, fear, anguish and insecurity. I3, when reporting his loneliness on the streets, gives visibility to the first feeling that affects a homeless person ${ }^{(22)}$. It is noteworthy that, in order to provide care for these people, it is necessary to question the notion of vulnerable while fragile, in need of help, and that they do not know how to take care of themselves; in this perspective, the knowledge of specialists is highlighted at the expense of the knowledge of these people, disqualifying the way these people take care of themselves and organize their lives ${ }^{(23)}$. In reality, they are resilient people, with a lot of wisdom about their lives, the ways of facing life on the streets, their adversities, and who have several different experiences.

The aspects presented by participants as a definition of health, such as family, spirituality, mental health, eating conditions, hygiene, work, require attentive listening by professionals in a dialogue attitude and not a judgment of values.

Some participants $(13,15,16,18)$ highlight the discrimination they suffered when seeking care in health services. Studies show that the delay and difficulty in seeking care is due to the prejudice and discrimination suffered by the condition of hygiene, clothing, fetid odor, lack of documentation for identification and registration, in addition to previous episodes of poor service and even a ban on entering public establishments ${ }^{(5-6,24)}$.

Facing such situations, the reports alongside the literature indicate that these people are discouraged from seeking and entering health services, which makes their search for care happen only when they no longer withstand the symptoms. Cases of vehicular run-overs, falls, fights and health problems related to the respiratory system are the causes of greater demand for health services. Basic Health Units and Emergency Units are the most used services, suggesting difficulty in promoting health monitoring of these people. Therefore, the way services 
are organized to welcome HP, together with the perception by homeless people that they should seek help only in more serious situations - urgency or emergency -, demonstrate the influence of the biomedical model, as it focuses care on signs and symptoms of diseases, it is little comprehensive, it is enlarged, and its centrality is not in the person ${ }^{(5,16,25-26)}$.

Only 2 interviewees (I1 and I9) refer to monitoring in health services and both are HIV-positive. This, together with I2's statement, which associates the perspective of health with the risk of HIV contamination, leads to reflection on the reason for seeking service, whether it is due to an already established cause or if there is an interest in broader health monitoring in a different way. According to some references, Sexually Transmitted Infections (STIs) are among the most recurrent health problems in this population ${ }^{(24)}$. Life on the streets is a situation of increased discrimination and violence, factors that, when related to each other, increase vulnerability to HIV infection and illness due to Acquired Immune Deficiency Syndrome (AIDS) (24).

On the other hand, the fact that there was a demand for health services may indicate the recognition of care and construction of bonds ${ }^{(24)}$. It is interesting to note that people who sought care were already affected by diseases, indicating weakness in prevention and health promotion in a broader way.

In the search for health services, obstacles can be found, such as: difficulty in locomotion, lack of perspective on the future that implies health care, lack of qualified professionals to serve this population, and the fear of suffering prejudice, as mentioned previously ${ }^{(6)}$. In spite of this, it is relevant to note that Ordinance Ministry of Health/Minister's Office No. 940 of April 28, 2011, article $23, \S 1^{\circ}$, exempts gypsies, nomads and homeless people from presenting their home address to acquire the SUS Card (public health care system card) ${ }^{(27)}$. Such a measure reflects a strategy to minimize an aspect that could pose as another access barrier.

Health professionals have a responsibility to HP, especially those in Primary Care, since it is the users' gateway to the service. They should prioritize monitoring homeless people in the network and provide the necessary care for them, with the fulfillment of their professional ethics. Moreover, they must take into account the difficulty of accessing the unit and also of professionals in carrying out embracement ${ }^{(28-29)}$. In this regard, nursing professionals must be attentive and have a sensitive look at $\mathrm{HP}$, as they are generally responsible for embracing users in primary care units and other health services.

People seek welcoming, support and shelter on the street, even if they are exposed to inadequate health, housing and food conditions $^{(26)}$. As pointed out, illness can become a mandatory outcome in the life of HP, because life on the street is both the cause and the consequence of health problems. "There are those who go to live on the street and, therefore, get sick and there are those who get sick and, therefore, go to live on the street"(24). Exclusion is intensified by lack of access to formal jobs, good quality education and health services. Consequently, forms of social representation emerge, which contributes to a negative image of $\mathrm{HP}$, interfering in the attitudes and behaviors of professionals who provide care and impairing the care process ${ }^{(16,29)}$.

The reported testimony in the research diary, in which the interviewed person states that new graduates are negatively influenced and repeat the behavior of other professionals, points to the need for strategies that can prevent this from occurring. A study points out the importance of developing activities with attentive listening to this population, involving students and professionals ${ }^{(30-31)}$.

It is observed that some participants bring the belief that the service will occur according to their behavior, thus giving rise to other forms of social representation. 16 states that in situations that reveal the need for care, he assumes a "somewhat aggressive" attitude, showing that he really needs the service. 11 and 12 point to the perception of exchange and merit, in which for one to be respected it is necessary to respect first.

Approach and embracement are essential to provide care to $\mathrm{HP}$, since exclusion occurs even in health services, where their presence is sometimes uncomfortable for both professionals and other users, with the right to comprehensive health care almost always being denied ${ }^{(24)}$.

Contrasting the statements of discrimination, three of the participants affirm positive experiences in health care. However, as the study problematizes ${ }^{(17)}$, it is necessary to think if the satisfaction on the part of HP would be due to the fact that they are able to get some care and the low expectations presented by them, which generates less demanding standards. Another point is that service is often seen as a charity or merit and not a right, as shown in 12's statement about the existence of some homeless people who do not deserve good care.

Starting from the concept of health as a right, it is necessary to seek means that can meet the needs of this public, such as the definition of health units as a reference for HP care, establishing a flow between them and the social protection network institutions, also another one between the academic studies and the sensitivity training of health professionals. Health professionals need a differentiated approach, tools and strategies that can support teams in addressing this specific population ${ }^{(27)}$. Efforts in this direction have been made in some experiences ${ }^{(1,30)}$.

Still in relation to professional performance, it is important to resume field diary records in which interviewees reveal apprehensions about professional practice and the way academic training of health professionals is structured. Undoubtedly, there are weaknesses in the training process and the issue of social vulnerability is not always addressed in nursing and health courses; when it is, there is a theoretical and superficial predominance. The topic needs to be discussed, paying attention to the socioeconomic and cultural context of people, in favor of comprehensive and humanized care. The existence of opportune academic spaces to approach this and other realities that are sometimes hidden is paramount.

Extension activities in which there is contact with the community are also of paramount importance. They ensure that students understand individual and collective needs, leading them as future professionals to discuss prevention and health promotion according to the reality of people, bringing them together and expanding the vision of co-responsibility for the health of the population in a given context; in this case, $\mathrm{HP}^{(32)}$.

Another aspect that unfolds from these reflections extends beyond the character of achievements with the approval of public policies. The idea of an apparent guarantee of inclusion 
Homeless people: health aspects and experiences with health services Prado MAR, Gonçalves M, Silva SS, Oliveira PS, Santos KS, Fortuna CM.

offered by them is a danger. Bearing that in mind, it is essential to recognize that, sometimes, these reflections do not get off the drawing board ${ }^{(33)}$. On the other hand, it must also be recognized there is a distortion in terms of understanding poverty and its consequences in reinforcing exclusion, as well as not recognizing citizenship and the rights of the other, making access to services distinct, demonstrating that there are still much to be done to actually ensure health care for this population.

Thus, it is necessary that everyone involved in HP care, as well as the people on the street, see health (with everything it encompasses in the view of HP - absence of pain, food, work, quality of life, family ties, spirituality, etc.) as a right and not as an offered charity. When considering that nursing affirms care as the center of its practice, it is necessary to recognize the various sides that understanding what it means to be healthy may present, in addition to understanding the strength of the context, culture, and social conditions on health status.

\section{Study limitations}

One limitation of the study is that it was carried out in an establishment that embraces this population, perhaps if people were interviewed on the streets or in health services, we would have other views. Another limitation is that specificities such as race/color, ethnicity and gender were not considered; these singularities could contribute to deepen reflections.

\section{Contributions to nursing}

The relevance of this study is based on the importance of presenting the understanding that homeless people have about healthcare services, giving them a voice, so that nursing and other areas of health sciences can fully recognize them, in order to provide embracing and quality services.

Concerning the innovative aspects offered by the present production, there is is the experience of listening to this population and their views on health care and treatment. It is also worth noting that strategies that value embracing, bonding, and that recognize different life projects, have a robust and innovative potential for the results associated with social well-being, especially concerning HP.

\section{FINAL CONSIDERATIONS}

The study showed that homeless people have perceived their health beyond the biological aspect, i.e., presented by absence of diseases, seeing it in the quality of life and in aspects necessary for it. With regard to experiences in health care, homeless people sometimes fail to perceive themselves as subjects with rights. Most still face discrimination, which makes them seek health services only in emergency situations. Moreover, services are not always prepared to receive this population, not understanding their care needs. However, the complexity of care involving HP must be taken into account.

It is important to recognize the impact of public policies, but also to guarantee the possibility for this group to recognize and be recognized as beings with rights. The State, health professionals and anyone who may be directly or indirectly involved in care must guarantee these rights. It is necessary that health professionals, including nurses, broaden their view about health and contribute to more holistic and humanized care for this population. It is believed that this discussion around HP should be addressed since the basic training of future health workers, in addition to the importance of continuing education in health services in relation to such a population that proves to be invisible.

We estimate that other studies can be carried out, such as listening to health workers who provide care to this population, as it would be of great value for understanding the needs of HP and the concepts that guide health practices.

\section{FUNDING}

We thank CNPq/PIBIC for the financial support through the granting of a Scientific Initiation scholarship, to CNPq for the Master and Doctorate scholarship and to the Program for The Improvement and Training of professors and technicians of the State University of Bahia (PAC - DT).

\section{ACKNOWLEDGMENT}

We thank the study participants, the POP Center and the employees who contributed to its realization.

\section{REFERENCES}

1. Pimenta MM. The homeless population in Porto Alegre. Civitas. 2019;19(1):82-104. doi: 10.15448/1984-7289.2019.1.30905

2. Omerov P, Craftman AG, Mattsson E, Klarare A. Homeless persons' experiences of health- and social care: A systematic integrative review. Health Soc Care Community. 2020;28:1-11. doi: 10.1111/hsc.12857

3. Ministério da Saúde (BR). Decreto no 7.053 de 23 de dezembro de 2009. Institui a Política Nacional para a População em Situação de Rua e seu Comitê Intersetorial de Acompanhamento e Monitoramento, e dá outras providências [Internet]. Brasília: Ministério da Saúde. 2009 [cited 2019 Feb 22]. Available from: http://www.planalto.gov.br/ccivil_03/_Ato2007-2010/2009/Decreto/D7053.htm

4. Instituto de Pesquisa Econômica Aplicada (IPEA). Pesquisa estima que o Brasil tem 101 mil moradores de rua. IPEA [Internet]. 2017 [cited 2019 Mar 14]. Available from: http://www.ipea.gov.br/portal/index.php?option=com_content\&view=article\&id=29303

5. Ministério da Saúde (BR). Saúde da população em situação de rua: um direito humano [Internet]. Brasília: Ministério da Saúde. 2014 [cited 2019 Jan 23]. Available from: http://bvsms.saude.gov.br/bvs/publicacoes/saude_populacao_situacao_rua.pdf

6. Hino P, Santos JO, Rosa AS. People living on the street from the health point of view. Rev Bras Enferm. 2018;71(suppl 1):684-92. doi: 10.1590/0034-7167-2017-0547 
7. Gray HM, Nelson SE, Shaffer HJ, Stebbins P, Farina AR. How do homeless adults change their lives after completing an intensive job-skills program? a prospective study. J Community Psychol. 2017;45(7):888-905. doi: 10.1002/jcop.21900

8. Mariano CM. Emenda constitucional 95/2016 e o teto dos gastos públicos: Brasil de volta ao estado de exceção econômico e ao capitalismo do desastre. Rev Investig Const [Internet]. 2017 [cited 2018 Sep 20];4(1):259-81. Available from: https://revistas.ufpr.br/rinc/article/ view/50289/31682

9. Morosini MVGC, Fonseca AF, Lima LD. Política Nacional de Atenção Básica 2017: retrocessos e riscos para o Sistema Único de Saúde. Saúde Debate. 2018;42(116):11-24. doi: 10.1590/0103-1104201811601

10. Congresso Nacional (BR). Constituição de 1988: Constituição da República Federativa do Brasil. Brasília, DF: Senado Federal: Centro Gráfico, 1988. 292p.

11. Ministério do Desenvolvimento Social e Combate à Fome (BR). Orientações Técnicas: Centro de Referência Especializado para População em Situação de Rua - Centro POP [Internet]. Brasília: Ministério da Saúde. 2011 [cited 2019 Jan 11]. Available from: http://www.mds.gov.br/ webarquivos/publicacao/assistencia_social/Cadernos/orientacoes_centro_pop.pdf.

12. Gomes DF, Elias FTS. Public policies of social assistance for homeless people: document analysis. Com Ciênc Saúde [Internet]. 2016 [cited 2018 Sep 22];27(2):151-158. Available from: http://bvsms.saude.gov.br/bvs/periodicos/ccs_artigos/politicas_publicas_\%20assistencia_\%20social.pdf .

13. Van Wijk LB, Mângia EF. Health care for Homeless People by the Network of Psychosocial Attention of Sé. Saúde debate. [Internet]. 2017; 41(115):1130-1142. doi: 10.1590/0103-1104201711511.

14. L'Abbate S. The history of Collective Health in Brazil: analysis of its political and educational politicies in articulation with Institutional Analysis. Mnemosine [Internet]. 2018 [cited 2019 May 30];14(2):236-262. Available from: https://www.e-publicacoes.uerj.br/index.php/ mnemosine/article/view/41691/pdf_386.

15. Flach DMA, Andrade M, Abrahão AL, Ribeiro WA, Abrantes CM, Tavares CMM. O diário como ferramenta de trabalho na análise institucional - a escrita implicada em um serviço de gestão em saúde. Rev Pró-UniverSUS [Internet]. 2017 [cited 2019 Feb 05];08(1):44-7. Available from: http://editora.universidadedevassouras.edu.br/index.php/RPU/article/view/888.

16. Minayo MCS. Pesquisa Social. Teoria, método e criatividade. Petrópolis, Rio de Janeiro: Vozes; 2001.80 p.

17. Barata RB, Carneiro-Jr N, Ribeiro MCSA, Silveira C. Health social inequality of the homeless in the city of São Paulo. Saúde Soc. 2015;24(Supl.1):219-232. doi: 10.1590/s0104-12902015s01019

18. Domingues F, Lima BM, Masi NT, Duarte LR. Perception of professionals of the family health strategy on the population health needs. Rev Fac Cienc Med Sorocaba. 2018;20(2);86-91. doi: 10.23925/1984-4840.2018v20i2a6

19. World Health Organization (WHO). Constituição da Organização Mundial da Saúde (OMS) [Internet]. 1946. [cited 2018 Oct 05]. Available from: http://www.direitoshumanos.usp.br/index.php/OMS-Organiza\%C3\%A7\%C3\%A3o-Mundial-da-Sa\%C3\%BAde/constituicao-daorganizacao-mundial-da-saude-omswho.html

20. Ministério da Saúde (BR). Lei no. 8.080, de 19 de setembro de 1990. Dispõe sobre a organização do SUS. Diário Oficial da União. 19 Set 1990.

21. Segre MO. Conceito de saúde. Rev. Saúde Pública [Internet]. 1997 [cited 2018 Oct 22];31(5):538-42. Available from: http://www.scielo.br/pdf/ rsp/v31n5/2334.pdf

22. Villa EA, Pereira MO, Reinaldo MAS, Neves NAP, Viana SMN. Sociodemographic profile of women in street situation and vulnerability for the use of psychoactive substances. Rev Enferm UFPE. 2017;11(5):2122-31. doi: 10.5205/1981-8963-v11i5a23367p2122-2131-2017

23. Paulon SM, Romagnoli R. When vulnerability becomes power (Potentia). Interação Psicol. 2018;22(03):178-87. doi: 10.5380/psi.v22i3.56045

24. Ministério da Saúde (BR). Secretaria de Atenção à Saúde. Departamento de Atenção Básica. Manual sobre o cuidado à saúde junto à população em situação de rua [Internet]. Brasília (DF):2012 [cited 2019 Feb 20]. Available from: http://189.28.128.100/dab/docs/ publicacoes/geral/manual_cuidado_populalcao_rua.pdf

25. Paiva IKS, Lira CDG, Justino JMR, Miranda MGO, Saraiva AKM. Homeless people's right to health: reflections on the problems and components. Ciênc Saúde Colet. 2016;21(8):2595-606. doi: 10.1590/1413-81232015218.06892015

26. Silva ICN, Santos MVS, Campos LCM, Silva DO, Porcino CA, Oliveira JF. Social representations of health care by homeless people. Rev EsC Enferm USP [Internet]. 2018;52:e03314. doi: 10.1590/s1980-220x2017023703314

27. Ministério da Saúde (BR). Portaria no 940 de 28 de abril de 2011. Regulamenta o Sistema Cartão Nacional de Saúde [Internet]. 2011 [cited 2019 Mar 14]. Available from: http://bvsms.saude.gov.br/bvs/saudelegis/gm/2011/prt0940_28_04_2011.html.

28. Simões TRBA, Couto MCV, Miranda L, Delgado PGG. Mission and effectiveness of Outdoor Clinics (Consultórios na Rua):na experience of consensus production. Saúde debate [Internet]. 2017; 41(114):963-975. doi: 10.1590/0103-1104201711423.

29. Abreu D, Oliveira WF. Healthcare of the people living in the streets: a challenge for the Street Clinic and for the Brazilian Unified National Health System. Cad Saúde Pública. 2017;33(2):e00196916. doi: 10.1590/0102-311X00196916

30. Pereira AGC, Gomes ID, Abreu LDP, Basílio FRF, Magalhães RM, Moreira FJF, Castro FM, Santos ML, Matos FB, Sampaio JV. The silence which screams in the center: a look at living with the population in the street situation. Cadernos ESP. Ceará [Internet]. 2019 [cited 2020 Jan 13];13(1):83-93. Available from: http://cadernos.esp.ce.gov.br/index.php/cadernos/article/view/172/166.

31. Campos A. Homeless population: a view from interprofessional education to the non-visible. Saúde Soc. 2018;27(4):997-1003. doi: 10.1590/ S0104-12902018180908. 
32. Trindade LL, Ferraz L, Ferraboli SF, Rubini B, Saldanha CT, Bordignon M, et al. A Formação Profissional na orientação da assistência aos grupos vulneráveis na Atenção Básica. Rev Enferm UFSM. 2015; 5(2):368-378. doi: 10.5902/2179769213738

33. Serafino I, Luz LCX. Policies for the adult population living on the streets: questions for debate. Rev Katál. 2015;18(1):74-85. doi: 10.1590/1414-49802015000100008 